\title{
THE NEW DICTIONARY OF SLOVAK LANGUAGE AS A SOURCE OF TERMINOLOGICAL INFORMATION
}

\section{Ján STOFFA}

\begin{abstract}
The study presents to readers the new dictionary of Slovak language, which can be considered as an important source of terminological information in spite of its general nature and existence of only two first volumes of it. A general characteristic of the dictionary as a source of linguistic information is presented and a special attention is devoted to the dictionary as a source of terminological information. Codification changes of many new terms (neologisms) and term elements are presented in the study, especially of terms adapted from foreign languages. The user can find in it basic information about literacy of terms, their derivations, and enables him/her quickly and reliably to identify vernacular, slang or other substandard and from other causes incorrect expressions which are used as improper equivalents of adequate literary and standard terms. The dictionary integrates in open or hidden form also other special dictionaries, e. g. one-language dictionary, dictionary of foreign words, dictionary of abbreviations, etymological dictionary, dictionary of synonyms, dictionary of homonyms, dictionary of diminutives and that one of opposites. The study points out also many hidden terms quoted as examples in entries of the dictionary.
\end{abstract}

Key words: dictionary of Slovak language, neologisms, terminological information.

\section{NOVÝ SLOVNÍK SLOVENSKÉHO JAZYKA AKO ZDROJ TERMINOLOGICKEJ INFORMÁCIE}

Resumé: Štúdia prezentuje čitatel’om nový slovník slovenského jazyka, ktorý možno, považovat' za mimoriadne významný zdroj terminologickej informácie aj napriek jeho všeobecnému charakteru a tomu, že zatial' vyšli iba prvé dva diely. Obsahuje všeobecnú charakteristiku slovníka ako zdroja všeobecnej jazykovednej informácie a osobitnú pozornost' venuje slovníku ako zdroju terminologickej informácie. Upozorňuje na viaceré kodifikačné zmeny mnohých termínov (neologizmov) a termínových prvkov, najmä mnohé zmeny formy termínov preberaných z iných jazykov po ich adaptácii. Použivatelovi slovník poskytuje základnú informáciu o spisovnosti termínov a ich ohýbaní a umožňuje rýchlo a spol'ahlivo identifikovat' hovorové, slangové, či iné subštandardné alebo z iných dôvodov nesprávne výrazy, ktoré niektorí používatelia nenáležite používajú ako ekvivalenty plnohodnotných spisovných termínov. V slovníku sú otvorenej alebo v skrytej forme integrované aj d’alšie slovníky, napr. výkladový slovník, slovník cudzích slov, slovník skrátenín, etymologický slovník, slovník synoným, slovník homoným a slovník opozít. Štúdia upozorňuje aj na množstvo termínov skrytých v heslových statiach slovníka.

Kl'účové slová: slovník slovenského jazyka, neologizmy, terminologická informácia.

\section{1 Úvod}

Medzi zdrojmi terminologickej informácie zaujímajú významné postavenie všeobecné slovníky príslušného národného jazyka. Posledný komplexný slovník slovenského jazyka (d’alej len SSJ) bol vydaný pred viac ako polstoročím (1) až (6). Odvtedy v slovenskom jazyku nastalo mnoho zmien a jeho slovná zásoba sa obohatila o tisíce nových slov, z ktorých značná čast' bola prevzatá $\mathrm{z}$ iných jazykov. V medziobdobí medzi vydaním uvedeného slovníka a začatím vydávania nového SSJ jeho prvým dielom (7) a následne druhým (8) boli a až do jeho kompletného vydania zostávajú pre používatel'ov hlavnými náhradnými zdrojmi Krátky slovník slovenského jazyka (9) a Pravidlá slovenského pravopisu (10). V oblasti cudzích slov a neologizmov majú používatelia k dispozícii viacero slovníkov cudzích slov, medzi ktorými za najkomplexnejší treba považovat' slovník (11).

Jazyková a terminologická gramotnost' i jazyková a terminologická kultúra používatel’ov slovenčiny v odbornej komunikácii vyžadujú používanie spisovných foriem termínov a termínových prvkov. Bežný používatel' jazyka, ktorého od ukončenia vzdelávania voblasti slovenčiny často delia aj desiatky rokov a ktorý vývoj slovenčiny po skončení školovania už 
nesleduje, má často problémy ako rýchlo a spol'ahlivo zistit' alebo overit' spisovnost' a jazykovú správnost' termínov a termínových prvkov s ktorými sa stretáva v svojej hovorenej i písanej odbornej komunikácii. Ciel'om tejto štúdie je predstavit' takémuto používatel'ovi nový SSJ ako mimoriadne významný, aktuálny a spol'ahlivý zdroj terminologickej informácie.

\section{Všeobecná charakteristika nového slovníka slovenského jazyka}

Nový SSJ (7) a (8) predstavuje moderne koncipované dielo neobyčajne vysokej kvality, ktoré vzniklo ako výsledok práce početného autorského kolektívu pracovníkov Jazykovedného ústavu Ludovíta Štúra Slovenskej akadémie vied v Bratislave a mnohých d’alších spolupracovníkov. Prvé dva diely obsahujú spolu 55711 heslových slov, pričom (7) ich obsahuje 30293 a (8) 25 418. Výber heslových slov sa opiera o mnohoročnú excerpciu z obrovského množstva prameňov a o databázu Slovenského národného korpusu, ktorá obsahuje viac ako pol miliardy textových slov. Pri tvorbe slovníka boli využité najmodernejšie prostriedky IKT.

Heslové slová sú v slovníku radené abecedne a polygraficky zvýraznené hnedou farbou. Za každým heslovým slovom nasleduje heslová stat', ktorá obsahuje mnoho d'alších informácií, alebo odkazový symbol na iné heslové slovo. Informácie uvádzané v heslových statiach sú uvedené v jednotnej štruktúre a v jednotnom poradí, pričom začiatky špecifických informácií sú lokalizované pomocou celého radu uvádzajúcich grafických značiek. Bezprostredne za heslovým slovom je v heslovej stati uvedená jeho gramatická charakteristika a za ňou informácia o jeho pôvode. Za ňou nasleduje normatívne a štylistické hodnotenie heslového slova a hlavný odbor použitia. Jadro heslového slova predstavuje definícia, resp. výklad významu heslového slová. Jej/jeho začiatok je lokalizovaný symbolom hnedej farby. Ak existujú, uvádzajú sa d’alej jeho synonymá a antonymá (slová s opačným významom) heslového slova. Rozsahom najväčšiu čast' heslovej state tvoria príklady použitia heslového slova, často aj s uvedením jeho významného používatel'a. Pomocou jednotných grafických symbolov sa v texte heslovej state uvádzajú d’alšie významné prihniezdované informácie, napr. dokonavé formy v prípade slovies, zdrobneniny, ustálené slovné spojenia a frazeologizmy. Homonymné pomenovania majú samostatné heslové state. V prípade viacvýznamových slov sú ich heslové state rozčlenené pomocou arabských číslic a uvedené charakteristiky sa uvádzajú pre každý význam heslového slova osobitne.

Popri základnej slovníkovej časti obidva diely obsahujú viaceré d'alšie informácie: zoznamy redaktorov, autorov a d'alších spolupracovníkov, ktorí sa podiel'ali na vypracovaní slovníka, zoznamy citovaných autorov a tiež zoznamy skratiek a značiek.. V prvom diele SSJ (8) je uvedený aj predhovor a pre používatel'a slovníka vel'mi dôležitá stat' o východiskách a zásadách spracovania slovníka. Osobitnú prílohu slovníka (7) tvorí zoznam geografických názvov existujúcich i bývalých obcí, resp. sídel v SR a pomenovaní ich obyvatel'ov.

V slovníku sú otvorene alebo v skrytej forme integrované aj d'alšie slovníky, napr. výkladový slovník, slovník cudzích slov, slovník skrátenín, etymologický slovník, slovník synoným, slovník geografických názvov, slovník homoným, slovník prefixoidov, slovník sufixoidov, slovník zdrobnenín a slovník opozít. Heslové state obsahujú aj množstvo jednoslovných alebo i viacslovných termínov skrytých v textoch heslových statí, ktoré však nie sú radené abecedne a mnohé $\mathrm{z}$ nich sa objavia ako heslové slová až v d’alších zväzkoch slovníka.

K významným prednostiam SSJ patrí aj vzorné dodržiavanie štátnej normy (12), napr. pri vynechávaní rádovej medzery a medzier po interpunkčných znamienkach.

\section{Nový SSJ ako zdroj terminologickej informácie}

Nový SSJ poskytuje záujemcovi o terminologickú informáciu mnoho užitočných informácií. K najvýznamnejším patria:

- Informácie o kodifikovanej forme desat'tisícov termínov a termínových prvkov $\mathrm{z}$ viac ako sto vedných alebo iných odborov predstavujúcich bud' priamo heslové slová, alebo sa vyskytujúcich v príkladoch uvedených $\mathrm{v}$ textoch heslových statí;

- Informácie o aktuálnom pravopise a význame mnohých termínov - neologizmov, napr. ec-karta, edukátor, emotikon, e-zin, faksimile, gofra, grafity, grant, kodér, lobing, lobista;

- Informácie o kodifikovaných variantných formách termínov - neologizmov, napr. adaptér / adaptor, e-mail / email, hacker / heker, harddisk / hard disk, hobby / hoby, chat / čet, joystick /džojstik; 
- Informácie o synonymných termínoch, napr. abstrakt / resumé, helikoptéra / vrtul'nik, hypertextový odkaz / link, interaktivita / interaktivnost', interfejs / rozhranie, internetbanking / internetové bankovníctvo; chronometer / časomer, interdisciplinárnost' / interdisciplinarita, intermolekulový

intermolekulárny;

- Informácie o adaptovaných formách neologizmov, ktoré sa pôvodne písali rovnako ako v cudzom jazyku, ale v súčasnosti sú už nespisovné, napr. díler, dizajn, dzajnér, džersej, džinsy, džip, ekvalizér, hardvér, kapučíno, klíring, lančmit, softvér (s pôvodným pravopisom dealer, design, designer, jersey, jeansy, jeep, equalizér, hardware, cappuccino, clearing, lunchmeat, software);

- Informácie o termínoch, ktoré sú spisovné vo variantných formách, z ktorých jedna je adaptovaná a druhá pôvodná alebo blízka $\mathrm{k}$ nej, napr. dampingový / dumpingový, džin / gin, fitcentrum / fitnescentrum, kombo / combo;

- Informácie o variantných formách už ustálených termínov, napr. aeroplán / eroplán, ceruza / ceruzka, hydrogenizácia / hydrogenácia, chlorácia / chlórovanie, chytadlo / chytač, lapač, kábeláž / kabeláž, klipsa / klipsňa, hladička / žehlička, chlebovka / chlebovnica, kupolovitý / kopulovitý;

- Informácie o alternatívnej výslovnosti termínov a iných pomenovaní, napr. airbus [érbus / érbas], cinzano [čindzáno / činzáno], laser [laser / lejzer];

- Informácie o hovorovom charaktere mnohých výrazov nezriedka používaných namiesto plnohodnotných štandardných termínov, napr. čezeta, činžiak, diesel, darling, deci, decimálka, dekel, delobuch, digitálky, dizertačka, drink, dvojcédečko, dvojdecovka, električenka, ešus, esemeska, esemeskovat, empétrojka, fachman, filc, fiatka, fitnesko, fordka, fortiel', fotit', fotka, fusak, fuška, gurtňa, gyps, halogén / halogénka, haprovat', harlejka / harleyka, hausnumero, hmoždinka, igelitka, inet, inetový, klíma (technický objekt), umelá hmota, kontrolka, kubík;

- Informácie o historických pomenovaniach, napr. damaska, derě́, galéra, hámor;

- Informácie o význame mnohých medzinárodných prefixoidov, nielen tradičných (napr. anti-, auto-, foto-), ale aj novších (napr. eko-, euro-, info-) a množstvo príkladov ich využitia v konkrétnych termínoch, často neologizmoch, tak v spojení s medzinárodnými (napr. ekocentrum, eurofil, infoservis) ako aj národnými termínovými prvkami (napr. ekohračka, eurodaň, infozákon). Nechýbajú ani termíny s ret'azením prefixoidov (napr. antihypertenzívum, ekoagroturistika, elektrokardiograf);

- Informácie o význame mnohých medzinárodných sufixoidov, napr. -fil, -lóg, téka, ako aj príklady termínov, v ktorých sa uplatňujú ako termínotvorné prvky, tak v spojení s medzinárodnými (napr. eurofil, geológ, infotéka), ako aj národnými termínovými prvkami (napr.čechofil, oceánológ, filmotéka);

- Informácie o existencii slov s opačným významom (opozít), napr. analogový / digitálny, číslicový; čistopis / koncept, eurofil / eurofób, explilicitne / implicitne, exteriér / interiér, extravilán / ilntravilán, heterocyklický / homocyklický; kompatibilita, kompatibilnost' / inkompatibilita, inkompatibilnost;

- Informácie o profesionalizmoch, napr. elmer, farma, fleš, flešový, garančka, hacknút' / heknút', hasák, hyplerlink, imbus / inbus, impakt faktor;

- Informácie o slangových výrazoch, napr. cvičko, diplomka, doškolovák, dusitko, elastáky, elektróny (disky z l'ahkých kovov), fáro, francuzák, gruziňák, guma (pneumatika, galuska), gumák, gympel / gympel', gyps, infrák, intrák; kazet’ák, komp;

- Informácie o kodifikácii mnohých nových, často používaných slovies, napr. četovat' / chatovat', e-mailovat' / emailovat', enternút' / enterovat, esemeskovat, faksimilovat, formátovat, gestorovaat, internetovat, interviewovat', klikat;

- Informácie o spôsobe odvodenia mnohých skrátenín, domácich (napr. $\check{C} K$ - Červený kríž, $D P H$ - daň z pridanej hodnoty, CHKO chránená krajinná oblast'), medzinárodných, (napr. $H D D$ - hard disc drive, DTP - desk top publishing, $D V D$ - digital video disc / digital versatile disc), historických (napr. $A . D$ - anno Domini, c. a k. - cisársky a král'ovský), textových (napr. $d$. $d$-de dato, etc - et cetera, $i$. e. - id est) ako aj o pravopise skratiek adademických a iných titulov (napr. Ing., PaedDr., RNDr.) a vedeckých a iných hodností (napr. Dr. h. c., DrSc., genpor., PhD) a pod;

- Informácie o hláskovaní mnohých medzinárodných skratiek v slovenskom kontexte, napr. $D V D$ [dé vé dé], $H D$ [há dé], [há dé dé], $H P$ [há pé], IT [í té];

- Informácie o variantných formách niektorých skrátenín, napr. čs. /čsl., detto / dtto, dpi,/ DPI, dpt,/Dpt, Dr. / dr., hi - fi / hifi, HP / 
hp, ib. / ibid., jr. / jun.; kb / KB / kbit / Kbit; kB / $K B$;

- Informácie o význame mnohých značiek, napr. značiek chemických prvkov (s uvedením ich medzinárodných názvov, od ktorých boli odvodené), medzinárodných poznávacích značiek motorových vozidiel, jednotiek rôznych veličín a i;

- Vel'ká väčšina definícií pojmov pomenovaných heslovými slovami uvedená v heslových statiach SSJ je didakticky transformovaná do formy zrozumitel'nej neodborníkom, vd'aka čomu sú využitel'né aj $\mathrm{v}$ edukačných procesoch;

- Vheslových statiach je v príkladových častiach uvedené mnoho skrytých definícií pojmov, ktorých pomenovania budú abecedne zaradené až do d'alších dielov, napr. v heslových statiach autorský, chvenie, ložisko, doska sú skryté definícia pojmov autorský hárok, tlmič chvenia, vôla ložiska, rezonančná doska;

- Informácie o synonymných formách niektorých prefixoidov, napr. agro- / agri (agrokomodita, / agrotechnika, / agrikultúra, chemi- / chemo- (chemigraf, chemizácia, I chemofógia, chemorezistencia, chemoterapia), iz/ izo (izobara, izoglosa, izomér);

- V slovníku sa uvádza aj mnoho názvov rôznych entít (napr. acylpyrín, indulona, jar), ktoré sa uvádzajú s malým začiatočným písmenom, zatial' čo názvy - značky, resp. obchodné názvy výrobkov s vel'kým (Acylpyrín, Indulona, Jar). Viaceré názvy sa uvádzajú $\mathrm{v}$ dvoch alebo i viacerých formách, napr. algol, / Algol / ALGOL, alveg / alweg/ Alweg, cobol / COBOL / Cobol, chemlon / chemlón, fortran / FORTRAN / Fortran, intercity / Intercity, kapron / kaprón;

- Informácie o odlišnom význame niektorých formou vel'mi blízkych slov, napr. blok $\neq$ blog, čiernobiely $\neq$ čierno-biely, elektromer $\neq$ elektrometer, elektrovodivý $\neq$ elektrovodný, exekút $\neq$ exekutivec $\neq$ exekútor $\neq$ exekvent; defibrátor $\neq$ defibrilátor, difuzér $\neq$ difúzor, dôvodný $\neq$ dôvodový, dvojčíslie $\neq$ dvojčislo, ikon $\neq i k o n a$ / ikonka, interpret $\neq$ interpretátor, komunikant $\neq$ komunikátor, lokátor $\neq$ lokalizátor;

- Informácie o vhodnejších variantoch niektorých výrazov napr. algebrický namiesto algebraický, už spomenutý, alebo už spominaný namiesto horespomenutý, horespominaný, alebo

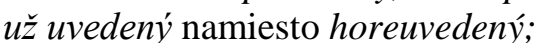

- Informácie o termínoch líšiacich sa zhl'adiska formy len interpunkčným znamienkom, ale podstatne odlišné svojím významom, napr. baza $\neq$ báza, bor $\neq$ bór, cer $\neq$ cér, dekan $\neq$ dekán, dom $\neq$ dóm, drén $\neq$ dreň, dvojtonový $\neq$ dvojtónový, fiala $\neq$ fiála, fuga $\neq$ fúga, grad $\neq$ grád, kutač $\neq$ kutáć; mys $\neq$ myš;

- Informácie o termínoch vyslovovaných rovnako ale líšiacich sa pravopisom, napr. bit $\neq$ byt, kivi $\neq$ kyvy, lira $\neq$ lýra, prefixoidy hipo $\neq$ hypo-;

- Informácie o zastaranosti mnohých pomenovaní (napr. černidlo, firhang, furma, grís / gríska) alebo tendencii $\mathrm{k}$ nej (napr. automat (zbraň), clonidlo, dvojgarsoniéra, francovka);

- Informácia o nesklonnosti mnohých termínov, napr. demo, filé, iglu, interview, klišée, komuniké;

- Informácie o pomenovaniach majúcich formu zdrobnenín, ale odlišný výnam ako má základné slovo (pseudodeminutívach), napr. čip $\neq$ čípok, diéta $\neq$ diétka, dvojhviezdicový $\neq$ dvojhviezdičkový, dvojplatňa $\neq$ dvojplatnička.

Obmedzený rozsah štúdie nám neumožňuje uviest' aj d'alšie pre používatel'ov zaujímavé informácie, napr. informácie o triviálnych pomenovaniach, citátových výrazoch a i.

\section{Niektoré obmedzenia a nedostatky nového SSJ z terminologického hl'adiska}

Základným objektívnym obmedzením nového SSJ, je že jeho prvé dva diely (7) a (8) pokrývajú iba menšiu čast' slovnej zásoby súčasného spisovného slovenského jazyka. V heslári i heslových statiach sa však vyskytujú aj niektoré menšie nedostatky, resp. nedôslednosti, napr.:

- Niektoré definície uvedené v heslových statiach sú nesprávne. Napr. elektroizolátor sa definuje nenáležite ako materiál a nie ako výrobok. Viaceré látky sa stotožňujú s látkami, v ktorých predstavujú iba ich zložku (napr. chlorid sodný, kremičitan hlinitý, kremik). Niektoré látky (heptán, hexán, izobután, izoprén) sa nesprávne definujú ako keby obsahovali len niekol'ko atómov uhlíka (ich počet sa vzt'ahuje nie na látku, ale na jej molekulu);

- V heslári SSJ absentujú pomenovania niektorých dôležitých pojmov, resp. termínových prvkov, napr. elektret, ferielektrikum, fotovoltický (často nahrádzaný bohemizmom fotovoltaický), hypervodič, prípadne niektoré dôležité významy heslových slov (napr. diera ako fiktívna častica v polovodičoch), niektoré dôležité prefixoidy (napr. cyklo-, feri- helio-, hipo-), niektoré skratky (z novších napr. ICT, IKT, LED, zo starších napr. ems, $k c ̌ s, k p$ ), kódové označenia štátov, niektoré so Slovenskom spojené názvy, napr. bralén, 
corgon̆ i niektoré zastarávajúce termíny typu fotorožok;

- V heslári absentujú niektoré dôležité synonymné termíny. Napr. pri termínoch aditívum, impregnátor, ingrediencia sa neuvádzajú ich synonymá prímes, impregnant, ingredient. Pri termínoch ingrediencia, izolátor sa ako synonymum nenáležite uvádzajú termíny primiešanina, izolant;

- V textoch definícií sa nerozlišujú pojmy izolant a izolátor, kvapalina a tekutina; plastická látka a plast, a tiež pojem internet od obchodného názvu Internet

- Za synonymá sa nenáležite považujú niektoré termíny napr. doštička / platnička, hmota / látka / materiál, izolant / izolátor / diekektrikum;

- V texte sa vyskytujú niektoré polotermíny, napr. audio,info, video;

- V texte sa vyskytujú niektoré nezmyselné pojmy, napr. kysličník berylnato-hlinitý,

- V texte sa vyskytujú niektoré nenáležité termíny, napr. kysličník uhličitý (spr. oxid uhličtý), kysličník uhol'natý. (spr. oxid uhol'natý), plastická látka, (spr. plast), plastická hmota (spr. plast), tekutina (spr. kvapalina);

- V heslári absentujú heslové slová pre mnohé rozšírené systémové medzinárodné prefixy (napr. bi- / di-, de- / dez-, im- / in-) a vysvetlenia ich významu, pričom ako heslové slová sú zaradené mnohé termíny, v ktorých sa vyskytujú;

- V texte heslových slov sú niektoré vágne pomenovania, napr. elektrina, oxid železa a titanu, zariadenie (v prípade heslového slova disk použité napr. namiesto termínu teleso);

- V texte heslových statí sa vyskytujú niektoré zastarané termíny, napr. fotoodpor (spr. fotorezistor), kruhová frekvencia (spr. uhlová frekvencia), merná hmotnost' (spr. hustota), merný elektrický odpor (spr. elektrická rezistivita), termoset ( $\mathrm{spr}$. reaktoplast);

- Niektoré významné skratky v heslári chýbajú, ale sú skryto definované v texte, napr. skratka GPS (globálny polohový systém), ktorá sa vyskytuje a vysvetl'uje v heslovej stati hesla lokátor, kde používatel' sotva môže predpokladat' jej výskyt a vysvetlenie jej významu.

\section{Záver}

Napriek niektorým objektívnym obmedzeniam a menším subjektívnym chybám a nedostatkom možno nový SSJ považovat' za jeden z najvýznamnejších zdrojov terminologickej informácie, ktorý poskytuje informácie o spisovnosti a oblastiach používania mnohých termínov, definíciu resp. výklad obsahu nimi pomenovaných pojmov, a mnoho d'alších dôležitých informácií o termínoch a termínových prvkoch. Nový SSJ by preto nemal chýbat' v osobnej knižnici žiadneho erudovaného odborníka a edukátora, ktorý komunikuje po slovensky.

\section{Zoznam bibliografických odkazov}

[1]Slovník slovenského jazyka : I. diel $a-k$. Red. Štefan Peciar. Bratislava: Vydavatel'stvo Slovenskej akadémie vied, 1959. 832 s.

[2] Slovník slovenského jazyka : II. diel l-o. Red. Štefan Peciar. Bratislava: Vydavatel'stvo Slovenskej akadémie vied, 1960. 648 s.

[3] Slovník slovenského jazyka : III. diel $p-r$. Red. Štefan Peciar. Bratislava: Vydavatel'stvo Slovenskej akadémie vied, 1963. 912 s.

[4] Slovník slovenského jazyka : IV. diel $s-u$. Red. Štefan Peciar. Bratislava: Vydavatel'stvo Slovenskej akadémie vied, 1964. 760 s.

[5] Slovník slovenského jazyka : V. diel v- ž. Red. Štefan Peciar. Bratislava: Vydavatel'stvo Slovenskej akadémie vied, 1965. 848 s.

[6] Slovník slovenského jazyka : VI. diel doplnky dodatky. Red. Štefan Peciar. Bratislava: Vydavatel'stvo Slovenskej akadémie vied, 1968. $336 \mathrm{~s}$.

[7] Slovník súčasného slovenského jazyka : $a-g$. Red. Klára Buzássyová a Alexandra Jarošová. Bratislava: Veda, 2006. 1134 s. ISBN 80-2240932-4.

[8] Slovník súčasného slovenského jazyka :H - L. Ed. Klára Buzássyová a Alexandra Jarošová. Bratislava: Veda, 2011. 1088 s. ISBN 978-80224-1172-1.

[9] Krátky slovník slovenského jazyka. Red. Ján Kačala, Mária Pisárčiková a Matej Považaj. 4. dopl. a upr. vyd. Bratislava: Veda, 2003. 985 s. ISBN 80-224-0750-X. 
[10] Pravidlá slovenského pravopisu. 3. upr. Slovenský ústav technickej normalizácie, 1998. a dopl. vyd. Bratislava: Veda, 2000. 590 s. ISBN $56 \mathrm{~s}$.

224-0655-4.

[11] ŠALING，S. - IVANOVÁ-ŠALINGOVÁ, Lektoroval: Prof. Ing. Mgr. Ondrej Baráth, CSc.

M. - MANÍKOVÁ, Z.: Vel'ký slovnik cudzich slov. 5. revid. a dopl. vyd. Bratislava - Prešov: Samo, 2008. 1184 s. ISBN 978-80-89123-07.

[12] STN 01 6910: December 1999, Pravidlá písania a úpravy písomností. 1. vyd. Bratislava:

Prof. Ing. Ján Stoffa, DrSc., emeritný profesor, Katedra technické a informační výchovy, Pedagogická fakulta UP, Žižkovo nám. 5, 771 40 Olomouc, ČR 